\title{
DEVELOPMENT OF SNAKES AND LADDERS GAME FOR PHYSICAL FITNESS EMPLOYEES OF PT BEST PROFIT MEDAN 2020
}

\author{
*Jony Damanik, Tarsyad Nugraha, Suprayitno \\ Correspondence: Fakultas Ilmu Keolahragaan,Universitas Negeri Medan, Medan, \\ Indonesia \\ Email: jonydamanik55@gmail.com
}

\begin{abstract}
This research was conducted at PT Best Profit Medan. The research treatment was carried out by adjusting the schedule during work holidays. The time of this research was carried out from October 2020 to November 2020. Subjects or users targeted in research on the development of the snake and ladder game on physical fitness for employees of PT Best Profit Medan. The issues in the small group in this study were 20 employees of PT Best Profit Medan, and the subjects in the large group in this study were 40 employees of PT Best Profit Medan. The research subjects were taken based on the purposive sampling technique with the following criteria: 1) for women in healthy body condition and not in a state of pregnancy, 2) for men whose body condition was healthy and did not suffer from internal diseases. This research method is a development method. The study results are small group product trials. From the value obtained, it is known that the empirical score obtained is $78.87 \%$ (Appropriate to Use), so it can be stated that the snake and ladder game product is effective. Large group trial, the results above are the results of the questionnaire distributed to the experts attached in the attachment and then calculated. The acquisition of the expert revision in the small group trial is $98.44 \%$ (Very Appropriate to Use), but in extensive group trial studies, it has been no revisions from experts. Fiealth and Recreation
\end{abstract}

Keywords: Development, Games, Snakes, and Ladders

\section{Introduction}

Physical fitness needed by children is different from that needed by adults. Physical fitness is the ability of a person's body to carry out daily work without experiencing significant fatigue (Surjadji, 2000:1). According to Surjadji (2000: 1), there are ten components of physical fitness, namely: (a) cardiovascular endurance, (b) muscle endurance, (c) muscle strength, (d) flexibility. (flexibility), (e) body composition, (f) speed of movement, (g) agility, (h) balance.

From the above understanding, it can be concluded that, if a person has good physical fitness, then the daily activities carried out can take place well so that they still have energy reserves to do other work. Physical activity, in this case, covers a fairly broad scope, which is commonly done in various types of work, leisure activities, and daily routine activities. The degree of physical fitness of a

PJKR

https://jurnal.unimed.ac.id/2012/index.php/jpehr 
person dramatically determines his physical ability in carrying out daily activities. The higher the degree of physical fitness of a person, the higher his physical workability. In other words, the results of their work will be more productive if their physical fitness increases. Most people today tend to be reluctant to do physical activity. If not addressed immediately, Habits like this can lead to a decline in organ function and can even have an impact on health. But this can be prevented through good and regular exercise. Sports activities carried out have many benefits, one of which is obtaining physical fitness which is very important for health. The higher needs of life make humans have to be able to fulfill them. To pursue these needs, humans must work even more challenging.

Modern business life demands excellent stamina from the perpetrators because they have to work with fast rhythms, tight and irregular schedules, unexpected changes in plans, and long working hours. Situations and working conditions like this cause work stress, resulting in various psychosomatic diseases such as gastric ulcers, cardiovascular diseases, etc. The disease requires a lengthy healing time, and costs are not small. In addition, sufferers are also forced not to come to work, so that employees and companies will suffer double losses, namely reduced income, and increased expenses. In addition to improving fitness status, physical fitness programs will also boost morale, prevent various diseases, relieve tension, increase self-confidence, form a sporty spirit, teach patience, be happy, and train concentration.

Some myths that often still exist in the company's ranks: 1 . Physical fitness programs (sports) require energy; work requires energy; how is it possible that a physical fitness program will support work?. This is precisely where the secret of the sport. The human body has a high ability to adapt (adaptation) to the burden placed on it. Once finished exercising, the body's endurance does go down. Still, after recovery, the immune system will rise higher than before so that with regular exercise, the body's resistance will increase gradually (like stairs). When working, specific muscles are used more dominantly than other muscles. If this continues, there will be an imbalance of muscle strength and flexibility. Exercise guarantees the return of that balance.

Sport costs money, facilities, equipment and also takes time. How can exercise save costs and increase work productivity? Sports vary from cheap to expensive, easy to difficult. You can choose the type of sport that suits the conditions and situations. It's like we lose Rp. 50,000 to get Rp. 250,000 - so it goes with the expenses that go out for sports purposes. The University of Toronto monitors the health conditions of two insurance companies. One company was given a physical fitness program, and the other was not. After six months, it was seen that in companies with physical fitness programs, the number of employees who were absent from work decreased by $22 \%$, and employees who had to be replaced due to illness decreased from $15 \%$ to $1.5 \%$. 3. Company directors often say, I don't need a lot of endurance, because I work behind a desk all day, and only watch television at night" (Wara, 2016:3). People who lack physical activity will yawn in the office, feel sleepy all day, fall asleep after eating a full meal, and 
feel tired from exerting a little more energy than usual (e.g., climbing stairs or walking fast). In addition, people with low fitness will become social creatures who are lame, too tired to play with children, too tired to eat out with their wife/husband, too tired to do anything other than sitting behind a desk and watch television.

The American Association of Fitness Directors in Business and Industry (AAFDBI) researched to prove that fit employees are more productive, so companies in America can now say that fitness programs produce high morale. The results of this study indicate the need for physical fitness programs in companies that provide benefits for employees, businesses, and industry (Wara, 2016:4).

Based on the results of observations, namely the author's interview with several employees conducted on June 26, 2019, at PT Best Profit Medan, there are problems related to physical fitness, namely lack of productivity in doing work such as easy sleepiness, lack of concentration, easy to experience fatigue due to the lack of sports activities carried out. By administrative, analytical, financial, and other employees. The workload that must be borne is huge, namely the PT Best Profit Medan employees for nine hours. To take such a large workload, of course, requires good physical fitness. To get a fit body, a person needs to do physical activities that involve components of physical fitness and through excellent and correct methods. From the discussion above, it can be said that physical fitness is essential to increase one's work productivity. It can be concluded that physical fitness is a person's ability to carry out daily work lightly and quickly without feeling fatigued, which means that it can optimize the productivity of human labor. To achieve excellent physical condition, a person can perform physical activities that involve components of physical fitness regularly.

Talking about physical activity, it has something to do with cardiorespiratory endurance. According to Len Kravitz (2001:5), "Cardiorespiratory endurance is the ability of the heart, lungs, blood vessels, and large muscle groups to perform hard exercises over a long period of time." With specific exercises, cardiorespiratory resistance will increase. The higher a person's physical ability, the higher the body's ability to handle the given workload, or in other words, it can increase one's work productivity. Based on the description above, the author is interested in developing a snake and ladder game applied to employees.

Snakes and Ladders is a board game for kids played by two or more people. The game board is divided into small squares, and on some of the courts, several "ladders" or "snakes" are drawn that connect them to other yards. This game was created in 1870 . There is no standard board game in snakes and ladders - everyone can create their board with a different number of squares, snakes, and ladders. Each player starts with their pawn in the first square (usually the square in the lower-left corner) and takes turns rolling the dice. Pawns are executed according to the number of dice that appear. If players land at the bottom end of a ladder, 
they can go directly to the other end of the ladder. When they land on a box with a snake, they have to go down to the box at the bottom end of the snake. The winner is the first player to reach the last square. Usually, when a player gets a six from the dice, they get one more turn. If not, then the turn goes to the next player.

In previous studies, the snake and ladder game was only developed as a medium in mathematics, accounting, and other subjects. However, in this study, researchers are interested in developing ideas for creating exciting games to be applied to employees in the company. Usually, companies have their game tricks such as outbound and others contained in family gatherings. In this study, the snake and ladder game developed was still the same as the snake and ladder game on paper. But the difference in implementing this snake and ladder game is on a football field or a reasonably large area. The researcher designed the boxes numbered 1-35. The package contains exercises that support one's physical fitness, where there are sit-ups, push-ups, sit and reach, and up and down benches where the purpose of this exercise is to improve the physical fitness of the employees. Each box in the first sequence is still in a few repetitions, but the higher the number of packages, the more repetitions of the exercise.

Based on the problem description above, the researchers are interested in conducting a study entitled "Development of Snakes and Ladders Game for Physical Fitness of Employees of PT. Best Profit Medan in 2020".

\section{Theoretical Study}

Physical fitness

Humans in everyday life will always be faced with various activities they face. A person can carry out his duties well if he is healthy. But just being healthy may not be enough, but he needs a certain degree of health, or in other words, he must have a degree of physical fitness. Physical fitness is often defined as a state of physical ability that can adjust the function of the body's organs to specific physical tasks and environmental-conditions that must be handled efficiently, without excessive fatigue, and have fully recovered before the arrival of the same job the next day.

Harsono (1988:153) suggests "if the level of physical fitness is good, there will be an increase in the ability and circulation and heart work, there will be an increase in strength, flexibility, speed, stamina and others, there will be a better economy of motion during exercise. , there will be a faster recovery in the organs of the body after exercise, and there will be a rapid response from our body organism whenever that response is needed."

\section{The Nature of the Game (Games)}

The term game comes from the primary word "play," which gets the suffix "role." According to Novi (2016: 59) in the Big Indonesian Dictionary, "playing is doing something pleasing to the heart (using tools or not). Thus, a "game" is something

PJKR_ 
that is used to play, an item or something to be played with; actions that are not taken seriously, are ordinary.

\section{Method}

In research on the development of the snake and ladder game to improve physical fitness for PT Best Profit Medan employees. It is a process used to develop and validate learning products. Research and development in this study use the Research \& Development (R \& D) development model from Borg \& Gall (1983:776), which consists of ten steps, including 1) Conducting research and gathering information (library review, subject observation, report preparation). subject matter) (2) Planning (defining skills, formulating goals, determining the order of teaching, and small-scale trials) (3) Developing initial product forms (product preparation, handbook preparation, and evaluation equipment) (4) Conducting field tests preliminary (using 20 subjects) (5) Revising the main product (according to the suggestions from the results of the initial field test) (6) Conducting the preliminary field test (with 40 subjects). (7) Revise the product (based on suggestions and results of the main field trials). (8) Field test with 40 subjects (9) Final product revision (10) Making reports on products in journals, working with publishers who can do commercial distribution.

\section{Result and Discussion}

Study of literature related to the problems studied and preparation for formulating a research framework. Based on the results of observations, namely the author's interview with several employees conducted on June 26, 2019, at PT Best Profit Medan, there are problems related to physical fitness, namely lack of productivity in doing work such as easy sleepiness, lack of concentration, easy to experience fatigue due to the lack of sports activities carried out. By administrative, analytical, financial, and other employees. The workload that must be borne is huge, namely the PT Best Profit Medan employees for nine hours. To handle such a large workload, of course, requires good physical fitness. To get a fit body, a person needs to do physical activities that involve components of physical fitness and through excellent and correct methods. From the discussion above, it can be said that physical fitness is essential to increase one's work productivity. It can be concluded that physical fitness is a person's ability to carry out daily work lightly and quickly without feeling fatigued, which means that it can optimize the productivity of human labor. To achieve excellent physical condition, a person can perform physical activities that involve components of physical fitness regularly. With specific exercises, cardiorespiratory resistance will increase. The higher a person's physical ability, the higher the body's ability to handle the given workload, or in other words, it can increase one's work productivity. Based on the description above, the author is interested in developing a snake and ladder game applied to employees.

The following is the snake and ladder game module in this study:

1) Procedures in the game

PJKR_

https://jurnal.unimed.ac.id/2012/index.php/jpehr 
- Snakes and Ladders game is played by individuals.

- One round of snakes and ladders is played only for five people; then the rest take turns with the others.

- If it has been determined who the order of 1,2,3,4 and 5 is through a draw, the game begins with player 1 .

- Player 1 rolls the dice, then pays attention to where the number is going; in each number, there is a task order that each player must do according to the provisions.

- The dice that get the number 6 will be repeated to increase the number of acquisitions.

- Those who get in the position of a snake must go down according to the provisions.

- Those who get in a high position must go up according to the provisions.

The snake and ladder game product development results were then tested in small groups to see the effectiveness of the existing products. 20 PT Best Profit Medan employees carried out the trial of this snake and ladder game product.

In the implementation of this small group trial, 20 employees seemed enthusiastic about doing this game. Each employee was curious and eager to try. However, in reality, there are still employees who are afraid of fatigue in playing snake and ladder games in the field. According to the researchers, small groups significantly increased the willingness to exercise in employees. Employees' response at the time of the study was that employees seemed curious about the game of snakes and ladders. Employees are very enthusiastic in learning to use audiovisual media, where several points that show employees are active are employees saying the game is exciting. The following describes the test results where the most employees stated very well on points: 1) I did not feel tired the next day. 2) This game creates positive energy and relaxes the mind. 3) do not find it difficult to work after being tired. 4) I feel happy with my friends. 5) The body is more fit and healthy after playing the game. 6) Feeling lighter after playing. 7) This game makes cooperation even more solid. 8) This game makes the team in work more silent. 9) This game is easy to play with friends.

Then do expert revision, game expert, and fitness expert:

Fitness expert's answer

- Hardodi Sihombing, M.Pd

1) I think it's appropriate because the element of fitness is already very dominant in this game.

2) The downside is that the banner is less attractive

3) Provide color for the banner. And slightly enlarge the box.

4) This game can be used as a sport that increases fitness not only among employees.

- Benny April. M, S.Pd, M.Pd

1) In my opinion, it is good because it will not feel like doing physical activity through the context of playing.

PJKR_

https://jurnal.unimed.ac.id/2012/index.php/jpehr 
2) The downside, the banner is plain white.

3) Give it an attractive color.

4) This game can be applied to all circles.

- Janner Sanjaya, M.pd

1) I think this game is perfect.

2) The downside is that between the ladder and the snake is too little.

3) Color between different ladders and snakes.

4) This game must be applied to all circles

Game Expert Answer

- Agus Salim Samosir, S.si, M.or, AIFO

1) I think it's appropriate because this game is meant to benefit all people.

2) I don't think it looks attractive yet.

3) Give it a bright color.

4) The hope is that this game can be developed into traditional sports games.

- Ramandan, S.Pd, MM, M.Pd, AIFO

1) I think this game is perfect.

2) There is no shortage problem, in my opinion.

3) It's just the color.

4) I hope everyone can get to know this game.

- Agustin Sastrawan Harahap, S.Pd, M.Pd

1) This game is perfect, can be applied to the development of traditional sports.

2) The problem of shortage is only in the color of the banner.

3) More attractive colors are given.

4) The hope is that this game can be an icon for family gatherings or all groups.

The suggestions and inputs from these six are not so many. It's just that all the experts emphasize the attractive appearance of the banner using bright colors so that the snake and ladder game players are interested in doing it. The snake and ladder game product development results were then tested in large groups to see the effectiveness of the existing products. 40 PT Best Profit Medan employees carried out the trial of this snake and ladder game product. The snake and ladder game carried out in a large group trial showed good employee enthusiasm so that it was straightforward to implement the snake and ladder game itself.

From the value obtained, it is known that the empirical score obtained is 81.93\% (Very Appropriate to Use). This means that this research is sufficient to determine the validity of the snake and ladder game applied to PT Best Profit Medan employees. The response of employees in large group trials has been better where the enthusiasm and enthusiasm of employees are getting better. Employees are also motivated, such as the narrative of the questionnaire results on the snake and ladder game that, on average, has a health impact according to them. The following is a review of the snake and ladder game product from an employee of PT Best Profit Medan: 1) I feel that it will be even better the next day. 2) I feel this game is appropriate for office people who rarely exercise. 3) I feel this game is appropriate to be applied to adults. 4) This game needs to be used as a game in a family gathering. 5) This game is less effective to be applied to employees who

PJKR_

https://jurnal.unimed.ac.id/2012/index.php/jpehr 
rarely exercise. 5) This game is not suitable for everyone. 6) This game is not suitable for age $>45$ years. 7) This game hurts health. Then it was given to the game and fitness experts, and the results were very suitable for use without any revision.

\section{Conclusion}

Small group product trial, from the obtained value, it is known that the empirical score is $78.87 \%$ (Appropriate to Use), so it can be stated that the snake and ladder game product is effective. Large group trial, the results above are the results of the questionnaire distributed to the experts attached in the attachment and then calculated. The acquisition of the expert revision in the small group trial is $98.44 \%$ (Very Appropriate to Use), but in extensive group trial studies, it has been no revisions from experts.

Suggestions based on the conclusions, the proposals put forward are as follows, this game can be done on the elderly, this game can be done on teenagers, this game makes someone forget the weight of the movement.

\section{References}

Borg. W. R \& Gall, M. D. 1983. Educational Research An Introduction. New York: Longman.

Harsono. 1988. Aspek-aspek Psikologi dalam Coaching. Jakarta: CV. Tambak Kusuma Jakarta.

Len Kravits. 2001. Body image in Preadolescent Girls. http://etd.unisa.ac.za/ETD$\mathrm{db} /$ theses/available/etd-06172008-100745/unrestricted/dissertation.pdf

Novi Mulyani. 2016. Super Asyik Permainan Tradisional Anak Indonesia. Yogyakarta: DIVA Pres

Surjadji. 2000. Psikologi Pendidikan dan Psikologi Sekolah (Direvisi dan Dilengkapi) Depok : Universitas Indonesia.

Wara, Fathul Mujib, Nailur Rahmawati. 2016. Metode Permainan-Permainan Edukatif Dalam Belajar Bahasa Arab. Yogyakarta: DIVA Pres.

PJKR

https://jurnal.unimed.ac.id/2012/index.php/jpehr 